\title{
APLIKASI ANALYTICAL HIERARCHY PROCESS (AHP) PADA PEMILIHAN SOFTWARE MANAJEMEN PROYEK
}

\author{
Siti Komsiyah \\ Mathematics Department, School of Computer Science, Binus University \\ Jl. K.H. Syahdan No. 9, Palmerah, Jakarta Barat 11480 \\ citie_math@binus.ac.id
}

\begin{abstract}
The problem with many alternative decisions in the areas of management and administration commonly referred to as multi-attribute decision problems. For example, the decision problem with many variables so that the target decision can not always be determined easily. Well-known method of approach, to overcome this kind of problem is called the Analytical Hierarchy Process (AHP). AHP technique is given by arranging alternative levels of decision, so as to provide a structured quantitative description. Application of multi-attribute types of problems such as problems in the selection of software, car, project proposal, the university, the best employees, and so forth. In this paper, the approach developed using the AHP in software selection project management.
\end{abstract}

Keywords: multi attribute decision, Analytical Hierarchy Process (AHP), selection of project management software

\begin{abstract}
ABSTRAK
Permasalahan keputusan dengan banyak alternatif dalam bidang manajemen dan administrasi biasa disebut dengan masalah multi attribute decision. Misalnya pada masalah pengambilan keputusan dengan variable yang banyak sehingga sasaran keputusan tidak selalu dapat ditentukan dengan mudah. Metode pendekatan yang terkenal untuk mengatasi masalah seperti ini disebut dengan Analytical Hierarchy Process (AHP). Teknik AHP diberikan dengan menyusun tingkatan alternative keputusan sehingga dapat memberikan gambaran kuantitatif yang terstruktur. Aplikasi permasalahan jenis multi-attribute misalnya masalah pada pemilihan software, mobil, proposal proyek, universitas, karyawan terbaik dan lain sebagainya. Dalam paper ini dikembangkan pendekatan menggunakan AHP dalam pemilihan software manajemen proyek.
\end{abstract}

Kata kunci: multi attribute decision, Analytical Hierarchy Process (AHP), penentuan software manajemen proyek 


\section{PENDAHULUAN}

Sumber kerumitan masalah keputusan bukan hanya ketidakpastian atau ketidaksempurnaan informasi tetapi banyak faktor yang berpengaruh terhadap pilihan-pilihan yang ada seperti kriteria pemilihan yang beragam dan pengambilan keputusan yang lebih dari satu. Jika sumber kerumitan itu adalah beragamnya kreteria, maka analytical hierarchy process (AHP) merupakan teknik untuk membantu menyelesaikan masalah ini. AHP diperkenalkan oleh Thomas L.Saaty pada periode 19711875. Dalam perkembangannya, AHP tidak saja digunakan untuk menentukan prioritas pilihan-pilihan dengan banyak kriteria, tetapi penerapannya telah meluas sebagai metode alternatif untuk menyelesaikan bermacam-macam masalah, seperti memilih portofolio, analisis manfaat biaya, peramalan dan lain-lain. (Mulyono, 2004). Misalnya aplikasi AHP dalam pemilihan perusahaan Badan Usaha Milik Negara (BUMN) sebagai tempat kerja mahasiswa (Sinaga, 2010) dan aplikasi lainnya pada pemilihan penyedia logistik (Vijayvargiya \& Dey, 2010).

Pada paper ini akan diberikan aplikasi AHP pada pemilihan software yang digunakan pada management proyek. Pendeknya, AHP menawarkan penyelesaian masalah keputusan yang melibatkan seluruh sumber kerumitan seperti yang diidentifikasi di atas. Hal ini karena AHP cukup mengandalkan pada intuisi sebagai input utama, namun intuisi harus datang dari pengambilan keputusan yang cukup informasi dan memahami masalah keputusan yang dihadapi. Pada dasarnya AHP adalah suatu teori umum tentang pengukuran yang digunakan untuk menemukan skala rasio baik dari perbandingan pasangan yang diskrit maupun kontinyu. Perbandingan-perbandingan ini dapat diambil dari ukuran aktual atau dari suatu skala dasar yang mencerminkan kekuatan perasaan dan preferensi relative. AHP memiliki perhatian khusus tentang penyimpangan dari konsistensi, pengukuran dan pada ketergantungan didalam dan diantara kelompok elemen strukturnya. (Mulyono, 2004).

\section{METODE}

Secara umum pengambilan keputusan dengan metode AHP didasarkan pada langkah-langkah berikut: (1) Mendefinisikan masalah dan menentukan solusi yang diinginkan. (2) Membuat struktur hirarki yang diawali dengan tujuan umum, dilanjutkan dengan kriteria-kriteria dan alternaif-alternatif pilihan yang ingin di-rangking. (2) Membentuk matriks perbandingan berpasangan yang menggambarkan kontribusi relative atau pengaruh setiap elemen terhadap masing-masing tujuan atau kriteria yang setingkat di atas. Perbandingan dilakukan berdasarkan pilihan atau judgement dari pembuat keputusan dengan menilai tingkat kepentingan suatu elemen dibandingkan elemen lainnya. (3) Menormalkan data yaitu dengan membagi nilai dari setiap elemen di dalam matriks yang berpasangan dengan nilai total dari setiap kolom. (4) Menghitung nilai eigen vector dan menguji konsistensinya, jika tidak konsisten maka pengambilan data (preferensi) perlu diulangi. Nilai eigen vector yang dimaksud adalah nilai eigen vector maksimum yang diperoleh dengan menggunakan matlab maupun dengan manual. (5) Mengulangi langkah 3, 4, dan 5 untuk seluruh tingkat hirarki. (6) Menghitung eigen vector dari setiap matriks perbandingan berpasangan. Nilai eigen vector merupakan bobot setiap elemen. Langkah ini untuk mensintesis pilihan dalam penentuan prioritas elemen-elemen pada tingkat hirarki terendah sampai pencapaian tujuan. (7) Menguji konsistensi hirarki. Jika tidak memenuhi dengan consistency ratio CR < 0,100; maka penilaian harus diulang kembali.

Rasio Konsistensi (CR) merupakan batas ketidakkonsistenan (inconsistency) yang ditetapkan Saaty. Rasio Konsistensi (CR) dirumuskan sebagai perbandingan indeks konsistensi (RI). Angka pembanding pada perbandingan berpasangan adalah skala 1 sampai 9, di mana:

Skala 1 = setara antara kepentingan yang satu dengan kepentingan yang lainnya

Skala 3 = kategori sedang dibandingkan dengan kepentingan lainnya

Skala 7 = kategori amat kuat dibandingkan dengan kepentingan lainnya 
Skala 9 = kepentingan satu secara ekstrim lebih kuat dari kepentingan lainnya.

Skala 2,4,6,8 = nilai diantara dua penilaian yang berdekatan

Prioritas alternatif terbaik dari total rangking yang diperoleh merupakan rangking yang dicari dalam Analytic Hierarchy Process (AHP) ini. (Taha, 2011)

\section{HASIL DAN PEMBAHASAN}

Dalam menentukan tingkat kepentingan dari elemen-elemen keputusan pada setiap tingkat hirarki keputusan, penilaian pendapat dilakukan dengan menggunakan fungsi berfikir, dikombinasikan dengan preferensi perasaan dan penginderaan. Penilaian dapat dilakukan dengan komparasi berpasangan yaitu dengan membandingkan setiap elemen dengan elemen lainnya pada setiap kriteria sehingga didapat nilai kepentingan elemen dalam bentuk pendapat yang bersifat kualitatif tersebut digunakan skala penilaian Saaty sehingga akan diperoleh nilai pendapat dalam bentuk angka (kuantitatif). Berikut pada gambar 1 yaitu ilustrasi skema permasalahan penentuan prioritas penggunaan software manajemen proyek disertai kode fitur software dan perusahaan penyedia fitur dari atribut tersebut.

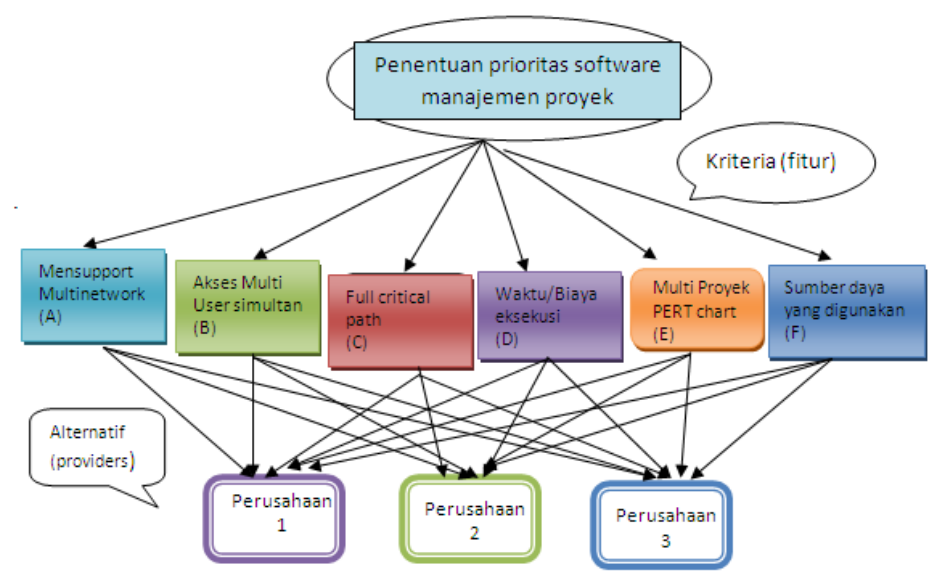

Gambar 1 Skema prioritas penggunaan software manajemen proyek

\section{Perhitungan Faktor Pembobotan Hirarki untuk Semua Kriteria} berikut:

Matriks perbandingan hasil preferensi dengan skala Saaty diperoleh pada tabel 1 sebagai

Tabel 1 Matriks (dengan skala Saaty) Perbandingan Berpasangan

\begin{tabular}{ccccccc}
\hline & A & B & C & D & E & F \\
\hline A & 1 & $1 / 2$ & $1 / 6$ & $1 / 2$ & $1 / 2$ & $1 / 6$ \\
B & 2 & 1 & $1 / 5$ & 1 & 1 & 1 \\
C & 6 & 5 & 1 & 3 & 4 & 1 \\
D & 2 & 1 & $1 / 3$ & 1 & 4 & $1 / 2$ \\
E & 2 & 1 & $1 / 4$ & $1 / 4$ & 1 & $1 / 4$ \\
F & 6 & 1 & 1 & 2 & 4 & 1 \\
\hline
\end{tabular}


Matriks Faktor Pembobotan Hirarki untuk Semua Kriteria yang disederhanakan dapat diperoleh pada tabel 2 berikut ini

Tabel 2 Matriks Pembobotan Hirarki yang disederhanakan

\begin{tabular}{lcccccc}
\hline & A & B & C & D & E & F \\
\hline A & 1 & 0.5 & 0.167 & 0.5 & 0.5 & 0.167 \\
B & 2 & 1 & 0.2 & 1 & 1 & 1 \\
C & 6 & 5 & 1 & 3 & 4 & 1 \\
D & 2 & 1 & 0.333 & 1 & 4 & 0.5 \\
E & 2 & 1 & 0.25 & 0.25 & 1 & 0.25 \\
F & 6 & 1 & 1 & 2 & 4 & 1 \\
Total & 19 & 9.5 & 2.95 & 7.75 & 14.5 & 3.917 \\
\hline
\end{tabular}

Dengan unsur-unsur pada tiap kolom dibagi dengan jumlah kolom yang bersangkutan, akan diperoleh bobot relatif yang dinormalkan. Nilai vektor eigen dihasilkan dari rata-rata bobot relatif untuk setiap baris. Hasilnya dapat diperoleh tabel 3 berikut ini:

Tabel 3 Matriks Pembobotan Hirarki yang dinormalkan

\begin{tabular}{cccccccl}
\hline & $\mathrm{A}$ & $\mathrm{B}$ & $\mathrm{C}$ & $\mathrm{D}$ & $\mathrm{E}$ & $\mathrm{F}$ & Vector Eigen \\
\hline $\mathrm{A}$ & 0.052631579 & 0.052632 & 0.05661 & 0.064516 & 0.034483 & 0.042635 & 0.0505845 \\
$\mathrm{~B}$ & 0.105263158 & 0.105263 & 0.067797 & 0.129032 & 0.068966 & 0.255297 & 0.1219364 \\
$\mathrm{C}$ & 0.315789474 & 0.526316 & 0.338983 & 0.387097 & 0.275862 & 0.255297 & 0.3498908 \\
$\mathrm{D}$ & 0.105263158 & 0.105263 & 0.112881 & 0.129032 & 0.275862 & 0.127649 & 0.1426585 \\
$\mathrm{E}$ & 0.105263158 & 0.105263 & 0.084746 & 0.032258 & 0.068966 & 0.063824 & 0.07672 \\
$\mathrm{~F}$ & 0.315789474 & 0.105263 & 0.338983 & 0.258065 & 0.275862 & 0.255297 & 0.2582099 \\
\hline
\end{tabular}

Selanjutnya nilai eigen maksimum ( $\lambda$ maksimum) diperoleh dengan menjumlahkan hasil perkalian jumlah kolom matriks pembobotan pada tabel 2 dengan vektor eigen. Nilai eigen maksimum yang dapat diperoleh adalah:

$$
\begin{aligned}
\lambda_{\text {maksimum }}= & 19 \times 0.0505845+9.5 \times 0.1219364+2.95 \times 0.3498908+7.75 \times 0.1426585 \\
& +14.5 \times 0.07672+3.917 \times 0.2582099 \\
= & 6.381129651
\end{aligned}
$$

Karena matriks berordo 6 (yakni terdiri dari 6 kriteria), nilai indeks konsistensi yang diperoleh:

$$
C I=\frac{\lambda_{m a k s}-n}{n-1}=\frac{6.381129651-6}{6-1}=0.0762259
$$

Untuk $n=6$, maka nilai random index pada tabel Saaty adalah $R I=1.24$ (Mulyono S, 2004), maka

$$
C R=\frac{C I}{R I}=\frac{0.0762259}{1.24}=0.061473
$$

Di mana

$C I($ consistency index $)=$ Rasio penyimpangan $($ deviasi $)$ konsistensi

$\lambda_{\text {maks }}=$ Nilai eigen terbesar dari matriks berordo $n$

$n=$ Orde matriks 


$$
\begin{aligned}
& C R\left(\text { consistency Ratio) }=\begin{array}{l}
\text { Rasio Konsistensi (perbandingan indeks konsistensi dengan nilai } \\
\text { random indeks }(R I)
\end{array}\right. \\
& R I=\text { Random indeks pada tabel Saaty }
\end{aligned}
$$

Karena $C R<0,100$ berarti preferensi yang diperoleh adalah konsisten.

Dari hasil perhitungan pada tabel 3 di atas menunjukkan bahwa: kriteria Full critical path $(C)$ merupakan kriteria yang paling utama dalam pemilihan software manajemen proyek dengan bobot 0.3498908 atau $34,9 \%$, berikutnya adalah kriteria Sumber daya yang digunakan (F) dengan nilai bobot 0.2582099 atau 25,8 \%, kemudian kriteria Waktu/Biaya eksekusi (D) dengan nilai bobot 0.1426585 atau 14, 3\%, berikutnya kriteria Akses Multi User simultan (B) dengan nilai bobot 0.1219364 atau 12,2\%., kemudian kriteria Multi Proyek PERT (E) dengan bobot 0.07672 atau 7,7 \% dan selanjutnya kriteria Men-support Multi network (A) dengan bobot 0.0505845 atau 5\%.

\section{Perhitungan Faktor Evaluasi untuk Semua Kriteria}

\section{Perhitungan Faktor Evaluasi untuk Kriteria: Men-support Multinetwork (A)}

Matriks perbandingan berpasangan untuk kriteria Men-support Multinetwork (A) pada 3 jenis perusahaan penyedia fitur atributnya beserta matriks yang dinormalkan dapat dilihat pada tabel 4 berikut

Tabel 4 Matriks Faktor Evaluasi kriteria A

\begin{tabular}{lccccccc}
\hline & P1 & P2 & P3 & P1 & P2 & P3 & Vector Eigen \\
\hline P1 & 1 & 0.25 & 4 & 0.190476 & 0.181818 & 0.307692 & 0.226662 \\
P2 & 4 & 1 & 8 & 0.761905 & 0.727273 & 0.615385 & 0.701521 \\
P3 & 0.25 & 0.125 & 1 & 0.047619 & 0.090909 & 0.076923 & 0.071817 \\
Total & 5.25 & 1.375 & 13 & 1 & 1 & 1 & 1 \\
\hline
\end{tabular}

Nilai eigen maksimum yang dapat diperoleh adalah:

$\lambda_{\text {maksimum }}=5.25 \times 0.226662+1.375 \times 0.701521+13 \times 0.071817$

$$
=3.08819
$$

Karena matriks ber-ordo 3 (yakni terdiri dari 3 alternatif), nilai indeks konsistensi yang diperoleh:

$$
C I=\frac{\lambda_{\text {maks }}-n}{n-1}=\frac{3.08819-3}{3-1}=0.044095
$$

Untuk $n=3$, maka nilai random index pada tabel Saaty adalah $R I=0.58$ (Mulyono S, 2004), maka

$$
C R=\frac{C I}{R I}=\frac{0.044095}{0.58}=0.076
$$

Karena $C R<0,100$ berarti preferensi yang diperoleh adalah konsisten.

\section{Perhitungan Faktor Evaluasi untuk Kriteria: Akses Multi User simultan (B)}

Matriks perbandingan berpasangan untuk kriteria Akses Multi User simultan (B) pada 3 jenis perusahaan penyedia fitur atribut nya beserta matriks yang dinormalkan dapat dilihat pada tabel 5 berikut 
Tabel 5 Matriks Evaluasi kriteria B

\begin{tabular}{lccccccc}
\hline & P1 & P2 & P3 & P1 & P2 & P3 & Vector Eigen \\
\hline P1 & 1 & 2 & 5 & 0.588235 & 0.617284 & 0.5 & 0.568506 \\
P2 & 0.5 & 1 & 4 & 0.294118 & 0.308642 & 0.4 & 0.334253 \\
P3 & 0.2 & 0.24 & 1 & 0.117647 & 0.074074 & 0.1 & 0.09724 \\
Total & 1.7 & 3.24 & 10 & 1 & 1 & 1 & 1 \\
\hline
\end{tabular}

Nilai eigen maksimum yang dapat diperoleh adalah:

$\lambda_{\text {maksimum }}=1.7 \times 0.568506+3.24 \times 0.334253+10 \times 0.09724$

$$
=3.021845
$$

Karena matriks berordo 3 (yakni terdiri dari 3 alternatif), nilai indeks konsistensi yang diperoleh :

$$
C I=\frac{\lambda_{\text {maks }}-n}{n-1}=\frac{3.021845-3}{3-1}=0.0109225
$$

Untuk $n=3$, maka nilai random index pada tabel Saaty adalah $R I=0.58$ (Mulyono S, 2004), maka

$$
C R=\frac{C I}{R I}=\frac{0.0109225}{0.58}=0.0188
$$

Karena $C R<0,100$ berarti preferensi yang diperoleh adalah konsisten.

\section{Perhitungan Faktor Evaluasi untuk Kriteria: Full critical path (C)}

Matriks perbandingan berpasangan untuk kriteria Full critical path (C) pada 3 jenis perusahaan penyedia fitur atribut nya beserta matriks yang dinormalkan dapat dilihat pada tabel 6 berikut

Tabel 6 Matriks Evaluasi kriteria C

\begin{tabular}{lccccccc}
\hline & P1 & P2 & P3 & P1 & P2 & P3 & Vector Eigen \\
\hline P1 & 1 & 9 & 6 & 0.782473 & 0.75 & 0.8 & 0.777491 \\
P2 & 0.111 & 1 & 0.5 & 0.086854 & 0.083333 & 0.066667 & 0.078951 \\
P3 & 0.167 & 2 & 1 & 0.130673 & 0.166667 & 0.133333 & 0.143558 \\
Total & 1.278 & 12 & 7.5 & 1 & 1 & 1 & 1 \\
\hline
\end{tabular}

Nilai eigen maksimum yang dapat diperoleh adalah:

$\lambda_{\text {maksimum }}=1.2780 \times 0.777491+12 \times 0.078951+7.5 \times 0.143558$
$=3.017733$

Karena matriks berordo 3 (yakni terdiri dari 3 alternatif), nilai indeks konsistensi yang diperoleh :

$$
C I=\frac{\lambda_{\text {maks }}-n}{n-1}=\frac{3.017733-3}{3-1}=0.0088665
$$

Untuk $n=3$, maka nilai random index pada tabel Saaty adalah $R I=0.58$ (Mulyono S, 2004), maka

$$
C R=\frac{C I}{R I}=\frac{0.0088665}{0.58}=0.01529
$$

Karena $C R<0,100$ berarti preferensi yang diperoleh adalah konsisten. 


\section{Perhitungan Faktor Evaluasi untuk Kriteria: Waktu/Biaya Eksekusi (D)}

Matriks perbandingan berpasangan untuk kriteria Waktu/Biaya eksekusi (D) pada 3 jenis perusahaan penyedia fitur atribut nya beserta matriks yang dinormalkan dapat dilihat pada tabel 7 berikut

Tabel 7 Matriks Evaluasi kriteria D

\begin{tabular}{lccccccc}
\hline & P1 & P2 & P3 & P1 & P2 & P3 & Vector Eigen \\
\hline P1 & 1 & 0.5 & 0.25 & 0.142857 & 0.111111 & 0.157928 & 0.137299 \\
P2 & 2 & 1 & 0.333 & 0.285714 & 0.222222 & 0.21036 & 0.239432 \\
P3 & 4 & 3 & 1 & 0.571429 & 0.666667 & 0.631712 & 0.623269 \\
Total & 7 & 4.5 & 1.583 & 1 & 1 & 1 & 1 \\
\hline
\end{tabular}

Nilai eigen maksimum yang dapat diperoleh adalah:

$\lambda_{\text {maksimum }}=7 \times 0.137299+4.5 \times 0.239432+1.583 \times 0.623269$

$=3.025171$

Karena matriks berordo 3 (yakni terdiri dari 3 alternatif), nilai indeks konsistensi yang diperoleh:

$$
C I=\frac{\lambda_{\text {maks }}-n}{n-1}=\frac{3.025171-3}{3-1}=0.0125855
$$

Untuk $n=3$, maka nilai random index pada tabel Saaty adalah $R I=0.58$ (Mulyono S, 2004), maka

$$
C R=\frac{C I}{R I}=\frac{0.0125855}{0.58}=0.0217
$$

Karena $C R<0,100$ berarti preferensi yang diperoleh adalah konsisten.

\section{Perhitungan Faktor Evaluasi untuk Kriteria: Multi Proyek PERT Chart (E)}

Matriks perbandingan berpasangan untuk kriteria Multi Proyek PERT chart (E) pada 3 jenis perusahaan penyedia fitur atribut nya beserta matriks yang dinormalkan dapat dilihat pada tabel 8 berikut

Tabel 8 Matriks Evaluasi kriteria E

\begin{tabular}{cccccccc}
\hline & P1 & P2 & P3 & P1 & P2 & P3 & Vector Eigen \\
\hline P1 & 1 & 1 & 1 & 0.333333 & 0.4 & 0.25 & 0.327778 \\
P2 & 1 & 1 & 2 & 0.333333 & 0.4 & 0.5 & 0.411111 \\
P3 & 1 & 0.5 & 1 & 0.333333 & 0.2 & 0.25 & 0.261111 \\
Total & 3 & 2.5 & 4 & 1 & 1 & 1 & 1 \\
\hline
\end{tabular}

Nilai eigen maksimum yang dapat diperoleh adalah:

$$
\begin{gathered}
\lambda_{\text {maksimum }}=3 \times 0.327778+2.5 \times 0.411111+4 \times 0.261111 \\
=3.055556
\end{gathered}
$$

Karena matriks berordo 3 (yakni terdiri dari 3 alternatif), nilai indeks konsistensi yang diperoleh :

$$
C I=\frac{\lambda_{\text {maks }}-n}{n-1}=\frac{3.055556-3}{3-1}=0.027778
$$


Untuk $n=3$, maka nilai random index pada tabel Saaty adalah $R I=0.58$ (Mulyono S, 2004), maka

$$
C R=\frac{C I}{R I}=\frac{0.027778}{0.58}=0.0479
$$

Karena $C R<0,100$ berarti preferensi yang diperoleh adalah konsisten.

\section{Perhitungan Faktor Evaluasi untuk Kriteria: Sumber Daya yang Digunakan (F)}

Matriks perbandingan berpasangan untuk kriteria Sumber daya yang digunakan (F) pada 3 jenis perusahaan penyedia fitur atribut nya beserta matriks yang dinormalkan dapat dilihat pada tabel 9 berikut

Tabel 9 Matriks Evaluasi kriteria F

\begin{tabular}{cccccccc}
\hline & P1 & P2 & P3 & P1 & P2 & P3 & Vector Eigen \\
\hline P1 & 1 & 0.125 & 0.167 & 0.066667 & 0.076923 & 0.052731 & 0.06544 \\
P2 & 8 & 1 & 2 & 0.533333 & 0.615385 & 0.631512 & 0.59341 \\
P3 & 6 & 0.5 & 1 & 0.4 & 0.307692 & 0.315756 & 0.34115 \\
Total & 15 & 1.625 & 3.167 & 1 & 1 & 1 & 1 \\
\hline
\end{tabular}

Nilai eigen maksimum yang dapat diperoleh adalah:

$\lambda_{\text {maksimum }}=15 \times 0.06544+1.625 \times 0.59341+3.167 \times 0.34115$

$$
=3.026317
$$

Karena matriks berordo 3 (yakni terdiri dari 3 alternatif), nilai indeks konsistensi yang diperoleh:

$$
C I=\frac{\lambda_{\text {maks }}-n}{n-1}=\frac{3.026317-3}{3-1}=0.0131585
$$

Untuk $n=3$, maka nilai random index pada tabel Saaty adalah $R I=0.58$ (Mulyono S, 2004), maka

$$
C R=\frac{C I}{R I}=\frac{0.0131585}{0.58}=0.0227
$$

Karena $C R<0,100$ berarti preferensi yang diperoleh adalah konsisten.

\section{Perhitungan Total Rangking/Bobot Prioritas Global}

Dari seluruh evaluasi yang dilakukan terhadap keenam kriteria maka telah didapatkan matriks hubungan antara kriteria dengan alternatif yang jika dikalikan dengan matriks bobot (vector eigen kriteria) akan didapatkan total rangking seperti pada tabel 10 berikut ini.

Tabel 10 Matriks Bobot Alternatif

\begin{tabular}{cccccccc}
\hline & \multicolumn{1}{c}{$\mathbf{A}$} & $\mathbf{B}$ & $\mathbf{C}$ & $\mathbf{D}$ & $\mathbf{E}$ & $\mathbf{F}$ & $\begin{array}{c}\text { Bobot } \\
\text { alternatif }\end{array}$ \\
\cline { 2 - 7 } & 0.0505845 & 0.1219364 & 0.3498908 & 0.1426585 & 0.07672 & 0.2582099 & \\
\hline P1 & 0.226662 & 0.568506 & 0.777491 & 0.137299 & 0.327778 & 0.06544 & 0.41445536 \\
P2 & 0.701521 & 0.334253 & 0.078951 & 0.239432 & 0.411111 & 0.59341 & 0.322789708 \\
P3 & 0.071817 & 0.09724 & 0.143558 & 0.623269 & 0.261111 & 0.34115 & 0.26275491 \\
\hline
\end{tabular}


Dari hasil perhitungan dapat diketahui nilai akhir (total rangking) masing-masing perusahaan penyedia fitur atribut dari software manajemen proyek dan berdasarkan total rangking tersebut maka dapat dibuat urutan prioritas perusahaan penyedia fitur kriteria berdasarkan pada atribut software manajemen proyek yang dibutuhkan sebagai berikut pada tabel 11 di bawah ini.

Tabel 11 Matriks Urutan Prioritas

\begin{tabular}{|c|c|c|c|c|c|c|}
\hline \multirow{2}{*}{$\begin{array}{l}\text { Urutan } \\
\text { prioritas }\end{array}$} & \multicolumn{6}{|c|}{ Kriteria } \\
\hline & $\mathbf{A}$ & B & C & D & $\mathbf{E}$ & $\mathbf{F}$ \\
\hline 1 & P2 & P1 & P1 & P3 & P2 & P2 \\
\hline 2 & P1 & P2 & P3 & P2 & P1 & P3 \\
\hline 3 & P3 & P3 & P2 & P1 & P3 & P1 \\
\hline
\end{tabular}

\section{SIMPULAN}

Dari bobot alternatif pada tabel 10 di atas dapat diketahui bahwa urutan prioritas perusahaan penyedia fitur sesuai atribut untuk pemilihan software manajemen proyek adalah sebagai berikut: (1) Perusahaan 1 dengan bobot 0.4145536. (2) Perusahaan 2 dengan bobot 0.322789708. (3) Perusahaan 3 dengan bobot 0.26275491 . Sedangkan dari matriks urutan prioritas pada tabel 11 dapat disimpulkan bahwa sebagai evaluasi penilaian untuk perusahaan penyedia software manajemen proyek yaitu perusahaan 2 yang memenuhi prioritas utama terbanyak pada criteria A, E, dan F, berikutnya perusahaan 1 dan perusahaan 3 .

\section{DAFTAR PUSTAKA}

Mulyono, S. (2004). Riset Operasi. Edisi Kedua. Jakarta: Lembaga Penerbit Fakultas Ekonomi Universitas Indonesia

Sinaga, J. (2010). Penerapan Analytical Hierarchy Process (AHP) Dalam Pemilihan Perusahaan Badan Usaha Milik Negara (BUMN) Sebagai Tempat Kerja Mahasiswa Universitas Sumatera Utara (USU). Skripsi, Universitas Sumatera Utara, Medan

Taha, H. A. (2011). Operation Research, An Introduction. Ninth Edition. New Jersey: Pearson, Prentice Hall.

Vijayvargiya, A., Dey, A. K. (2010). An analytical approach for selection of a logistics provider. Management Decision, 48(3): 403-418 